\title{
Leaching of Chlorides, Sulphates, and Phosphates from Ashes Formed as a Result of Burning Conventional Fuels, Alternative Fuels, and Municipal Waste in Household Furnaces
}

\author{
Alicja Kicińska ${ }^{1, * \mathbb{D}}$ and Grzegorz Caba ${ }^{2}$ \\ 1 Department of Environmental Protection, Faculty of Geology, Geophysics and Environmental Protection, \\ AGH University of Science and Technology, Mickiewicza 30 Av., 30-059 Kraków, Poland \\ 2 MPO Department of Bulky Waste and Additional Services, Municipal Department of Sanitation Ltd., \\ Nowohucka 1, 31-580 Kraków, Poland; grzegorz.caba@mpo.krakow.pl \\ * Correspondence: kicinska@agh.edu.pl; Tel.: +48-12-617-33-70
}

\section{check for} updates

Citation: Kicińska, A.; Caba, G. Leaching of Chlorides, Sulphates, and Phosphates from Ashes Formed as a Result of Burning Conventional Fuels, Alternative Fuels, and Municipal Waste in Household Furnaces. Energies 2021, 14, 3936. https:// doi.org/10.3390/en14133936

Academic Editors: Charisios Achillas, Elisabetta Arato and

Christos Vlachokostas

Received: 26 April 2021

Accepted: 28 June 2021

Published: 30 June 2021

Publisher's Note: MDPI stays neutral with regard to jurisdictional claims in published maps and institutional affiliations.

Copyright: (c) 2021 by the authors. Licensee MDPI, Basel, Switzerland. This article is an open access article distributed under the terms and conditions of the Creative Commons Attribution (CC BY) license (https:// creativecommons.org/licenses/by/ $4.0 /)$.

\begin{abstract}
The aim of the study was to assess leaching of $\mathrm{Cl}^{-}, \mathrm{SO}_{4}{ }^{2-}$, and $\mathrm{PO}_{4}{ }^{3-}$ from ashes formed in household furnaces. The ashes were obtained following the combustion of conventional fuels, namely wood and hard coal, and alternative fuels with various fractions of municipal waste in a household boiler. Aqueous leachates of the ashes were used to determine concentrations of chlorides by titration (Mohr's method) (21.3-3049.6 mg/dm³), sulphates by the gravimetric method $\left(12.2-244.1 \mathrm{mg} / \mathrm{dm}^{3}\right)$, and phosphates by spectrophotometry $\left(0.01-67.2 \mathrm{mg} / \mathrm{dm}^{3}\right)$. It was found that co-combustion of municipal waste with plastic-coated paper cartons, diapers, or a mixed waste fraction leaves the greatest amount of ashes on the furnace grate. The highest amounts of $\mathrm{Cl}^{-}, \mathrm{SO}_{4}{ }^{2-}$, and $\mathrm{PO}_{4}{ }^{3-}$ were leached from ashes generated from burning a mix of wood and coals, or wood alone (different species). The addition of municipal waste to the process of burning the conventional and alternative fuels studied did not significantly increase $\mathrm{Cl}^{-}, \mathrm{SO}_{4}{ }^{2-}$, and $\mathrm{PO}_{4}{ }^{3-}$ content in aqueous extracts of ashes, the exception being diapers and plywood. In light of the study results, it was concluded that all the ashes could be reused (as an additive to concrete) except for the ash generated from the combustion of a mixed municipal waste fraction and coal (due to the content of $\mathrm{Cl}^{-}$) and diapers (due to the content of $\mathrm{PO}_{4}{ }^{3-}$ ). It was demonstrated that $\mathrm{Cl}^{-}, \mathrm{SO}_{4}{ }^{2-}$, and $\mathrm{PO}_{4}{ }^{3-}$ content in the entire set of samples and in individual ash groups is highly heterogeneous and variable.
\end{abstract}

Keywords: municipal waste; environmental risk; household furnaces; anions

\section{Introduction}

Burning municipal waste in household furnaces is a frequent and often uncontrolled practice in Polish rural areas [1,2]. The diversity of waste, its morphological and chemical composition, is associated with the presence of numerous hazardous substances which, when incinerated, undergo changes and accumulate in ashes [3-9]. These substances pose a potential threat for the soil and aquatic environment, as they are easily leached and incorporated in the geochemical cycle [10-13]. Unfortunately, the existing body of knowledge about the extent of this threat is insufficient, and this subject has not been fully studied and documented in scientific publications.

The term "ashes" is used to describe solid particles generated as a by-product in the process of thermal decomposition (combustion). On the other hand, the term "fly ashes" denotes combustion products, whose composition includes fractions that can be suspended in the air. Furnace waste comprises mixtures of ashes (including fly ashes) and slags, whose physical and chemical properties depend mainly on the type of fuel used and technological parameters of the furnace. The most commonly used household heating devices are furnaces and stoker-fired boilers with manual fuel feeding, and stokerfired retort boilers with automatic fuel feeding. An important factor characterising the 
combustion process in household furnaces is the low temperature of fuel incineration in contrast to industrial boilers used in e.g., power plants. The latter use temperatures (850-900 ${ }^{\circ} \mathrm{C}$ ) allowing for the decomposition of organic compounds without letting them transform into stable forms non-reacting with water. The main components of ashes are silicon oxide $\left(\mathrm{SiO}_{2}\right)$, aluminium oxide $\left(\mathrm{Al}_{2} \mathrm{O}_{3}\right)$, iron oxide $\left(\mathrm{Fe}_{2} \mathrm{O}_{3}\right)$, calcium oxide $(\mathrm{CaO})$, and magnesium oxide (MgO) [1]. However, ashes also contain other substances, such as chlorides, sulphates, and phosphates, whose high concentrations pose a threat to the environment and infrastructure [14-17].

The subject of incineration or co-incineration of municipal solid waste in the world, especially in China, has been presented in a paper by Kanhar et al. [18]. These authors indicated that it is a major challenge for environmental managers to dispose of incineration residues enriched with a vast range of heavy metals and soluble salts. Similar findings have been published by Horák et al. [19], who demonstrated the risk of incinerating solid fuels mixed with municipal waste. The subject of incinerating or co-incinerating various types of biomass, individually or in combination with solid fuels, has also been addressed by Bachameier et al. [20], Link et al. [21], Monedero et al. [22], or Suárez-Macías et al. [23].

In Poland, there over 3 million households heated with solid fuels [24]. About 10-13 million tons per year of solid fuels are burnt in furnaces in these households, including various types of coal and firewood. As a result of such a way of heating, over 2.5 million tons of ash and slag waste are formed annually, which is about $22 \%$ of the total amount of municipal waste generated (i.e., 11 million tons/year) [24]. Currently, in accordance with the definition of municipal waste set out in the Act on Waste [25], this waste should be classified in group 20, i.e., municipal waste together with fractions collected separately [26-28], and it is mostly disposed of together with mixed municipal waste.

In light of the above-listed facts and insufficient scientific investigations of the environmental issues presented, two hypotheses were investigated:

Hypothesis 1 (H1). Does the addition of municipal waste (segregated and/or non-segregated) to conventional and alternative energy fuels have a significant effect on the content of chlorides, sulphates, and phosphates in ashes generated from their combustion?

Hypothesis 2 (H2). Does burning municipal waste in household furnaces significantly increase the environmental risk related to the content of chlorides, sulphates, and phosphates is ashes?

For that purpose, samples of selected conventional (wood, coal) and alternative (straw, nuts, peat, sawdust) fuels were prepared with an addition of various fractions of municipal waste (textiles, plastic-coated paper cartons, plywood, paper, and cardboard). The material collected was incinerated in a household furnace, generating ashes that were assessed in terms of the degree of environmental risk through the following:

(i) Determining the relationship between the amount of ash generated and different groups of waste and fuels used in the combustion process;

(ii) Determining the content of $\mathrm{Cl}^{-}, \mathrm{SO}_{4}{ }^{2-}$, and $\mathrm{PO}_{4}{ }^{3-}$ in ashes generated from the combustion of fuels and municipal waste;

(iii) Comparing the correlations between the content of anions in different groups of fuels and waste;

(iv) Indicating possibilities or lack thereof to reuse ashes in light of the parameters analysed.

\section{Materials and Methods}

\subsection{Material Preparation}

The first stage of the study involved the selection, collection, and preparation of fuel material most commonly used in individual households. These samples included the following:

- Hard coal $(n=4)$ from various fuel storage sites: Małopolska (coal I), Mazowsze (coal II), Podkarpacie (coal III), and a sample of the so-called coal pellets, 
- Alternative fuels $(n=4)$, namely straw, peat, walnuts, and sawdust,

- Wood $(n=4)$, representing the following species: Fraxinus (ash), Sambucus nigra L. (black elder), Acacia Mill. (acacia), and Salix L. (willow); all species were obtained from the local tree stand logging,

- Municipal waste $(n=7)$, comprising the following fractions: paper, textiles, PET, plywood, plastic-coated paper cartons, diapers, and mixed waste (mix). Single-family household waste was collected separately and collectively.

In total, 19 different types of the so-called primary material were collected, about $5 \mathrm{~kg}$ per each sample, between November 2019 and March 2020. Next, the material was fragmented, homogenised, reduced, and divided into feed portions, about $0.05 \mathrm{~m}^{3}$ each.

The hard coal samples represented 3 lump grades: hard coal no. I (from a coal storage site in Małopolska) was coarse, with a lump size of $10-20 \mathrm{~cm}$, hard coal no. II (bought in a storage site in Mazowieckie Voivodeship) was finer, with a lump size of about 5-10 cm, and hard coal no. III (from Podkarpacie), which was the finest, resembling coal pellets, with a lump size of about $2-5 \mathrm{~cm}$.

The firewood had been obtained from a local logging site as fresh (non-dried) chopped logs.

Samples of alternative fuels were processed materials, which had previously been fragmented. The wheat straw bale had been dried for one year and, as was the case with the peat used (briquettes), it had a low moisture content (about 30\%). The walnut shells had been dried for two seasons. The sawdust had a multi-species composition.

Municipal waste represented a dry fraction, and it was collected in a separate container. All waste samples were processed by grinding or crushing.

The necessary technological condition for collecting representative ash samples was to use adequate equipment for cleaning the furnace after every incineration, isolating finer lots of the primary material, and storing it during analysis.

\subsection{Ash Sample Preparation}

The second stage involved combusting the material collected. Each of the primary materials yielded a portion of ash from which the study material was selected. The crucial aspect was to maintain similar combustion conditions and clean the furnace chamber before burning each portion of fuel. The primary materials were incinerated in a Keller $10 \mathrm{~kW}$ coal burning furnace (with a nominal heating capacity of $10 \mathrm{~kW}$, efficiency of $80 \%$, and maximum working pressure of $0.25 \mathrm{MPa}$ ). According to the manufacturer's specifications, the basic fuel for this type of boiler is hard coal of the pea and nut type, and the substitute fuel is lignite and weathered wood.

The following action plan was adopted when incinerating the fuels in the furnace (Figure 1): (1) placing a portion of the primary material in the furnace chamber, (2) incomplete combustion (gas burner was used to initiate combustion), (3) cooling the furnace and ash, (4) collecting all the ash into a container, (5) separating the coarse fraction through a sieve, and collecting an ash sample in a plastic, tight-seal bag. After incinerating each of the fuel portions, the furnace chamber and the bottom hopper were thoroughly cleaned mechanically and pneumatically. 


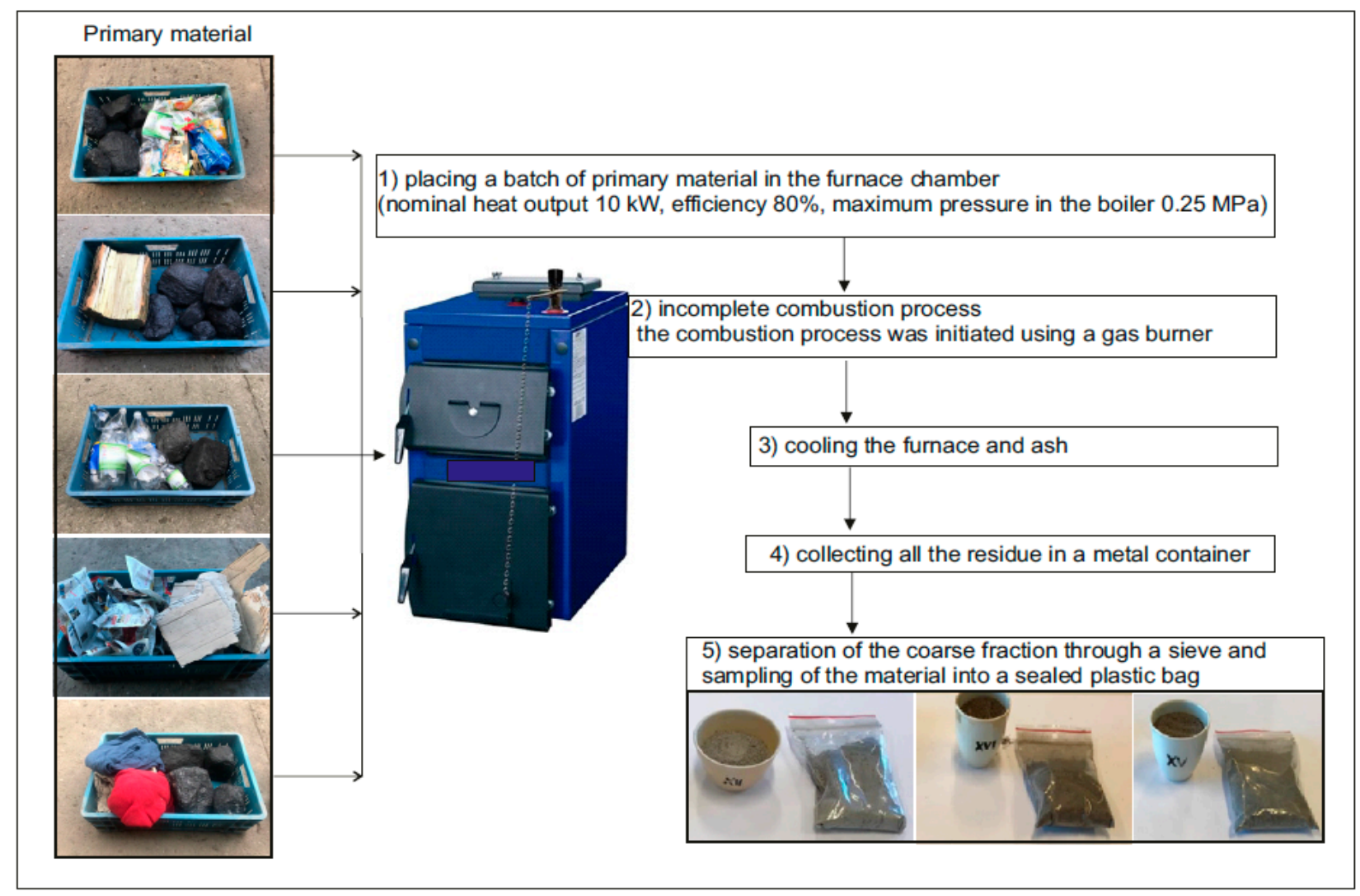

Figure 1. Scheme of fuel combustion in the household furnace.

The primary material was left to combust and naturally cool in its own time. The air supply was consistent for each incineration experiment. To obtain ash from the mixes of different groups of fuel and waste, the primary materials were placed in the furnace in equal proportions $(1: 1 \mathrm{v} / \mathrm{v})$. It was assumed that the conditions for primary material incineration resemble those that occur in individual household furnaces. The model of the furnace used to incinerate the primary material was not equipped with an in-built measurement system, as is the case with most of the furnaces in individual households. However, a pyrometer was used to measure the incineration temperature in the furnace chamber. The self-ignition temperatures measured (data in ${ }^{\circ} \mathrm{C}$ ) were as follows: $450-550$ for hard coal, 250-280 for peat, 210-320 for wood (different types), 230 for straw, 550 for coal pellets, and 180-260 for municipal waste (different types).

The metal container for ash was also cleaned and thoroughly dried after every incineration. A sieve with the same width of the separating groove $(\phi=1 \mathrm{~mm})$ was used for every sample.

Using the above methods, 23 ash samples were obtained, with the weight of about $1 \mathrm{~kg}$ each (Table 1). These were the products derived from the combustion of:

- Wood alone (ash, black elder, acacia, willow, and a mix of all 4 species) - 5 ash samples in total,

- Hard coal alone (coal I, coal II, coal III, and coal pellets) -4 ash samples in total,

- Alternative fuels alone (straw, peat, walnuts, and sawdust) -4 ash samples in total,

- Municipal waste alone (paper and cardboard, plywood, plastic-coated paper cartons, and diapers) -4 ash samples in total,

- Mix of wood and hard coal (ash + coal III, willow + coal I, acacia + coal III) - 3 ash samples in total,

- Mix of municipal waste and hard coal (textiles + coal I, PETs + coal I, and dry waste fraction mix + coal III) -3 ash samples in total. 
Table 1. Characteristics of ashes.

\begin{tabular}{|c|c|c|c|c|c|c|c|}
\hline Samples & Primary Material Type & {$[\mathrm{Kg}]$} & Colour of Ashes & \multicolumn{2}{|c|}{ Amount of Ashes [g] } & \multicolumn{2}{|c|}{ Amount of Unburned Material [g] } \\
\hline \multirow{4}{*}{$\begin{array}{l}3 \\
3 \\
0 \\
3 \\
3\end{array}$} & ash (Fraxinus) & 11.8 & very dark ashen & 106.6 & Medium * & 43.3 & a lot* \\
\hline & black elderberry (Sambucus nigra L.) & 12.1 & light grey & 100.1 & medium & 28.9 & little \\
\hline & acacia (Acacia Mill.) & 13.0 & light grey & 101.4 & little & 31.2 & little \\
\hline & acacia + elderberry + ash + willows & 12.2 & light grey & 111.8 & a lot & 35.1 & medium \\
\hline \multirow{4}{*}{$\begin{array}{l}0 \\
0 \\
0 \\
0\end{array}$} & $\operatorname{coal}(\mathrm{I})$ & 22.1 & light grey & 1850.1 & little & 630.2 & little \\
\hline & coal (II) & 21.5 & light grey & 4080.5 & a lot & 590.9 & little \\
\hline & $\operatorname{coal}(\mathrm{III})$ & 22.8 & light grey & 2330.2 & medium & 593.6 & little \\
\hline & coal pellets (ekogroszek) & 18.9 & light grey & 1812.2 & little & 460.1 & little \\
\hline \multirow{4}{*}{ 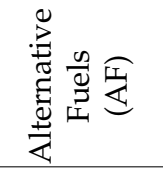 } & straw & 0.8 & very dark ashen & 113.3 & a lot & 53.7 & a lot \\
\hline & peat & 2.8 & light grey & 127.1 & medium & 48.1 & medium \\
\hline & nuts & 1.5 & light grey & 102.2 & little & 45.5 & little \\
\hline & sawdust & 1.2 & very dark ashen & 107.3 & little & 52.1 & a lot \\
\hline \multirow{4}{*}{ 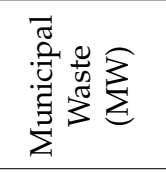 } & paper and cardboard & 1.1 & light grey & 124.3 & medium & 5.3 & little \\
\hline & plywood & 3.7 & dark ashen & 221.9 & medium & 37.6 & little \\
\hline & tetrapaks & 0.7 & light grey & 127.5 & a lot & 907.3 & a lot \\
\hline & diapers & 2.2 & very dark & 126.9 & a lot & 1230.0 & a lot \\
\hline \multirow{2}{*}{ 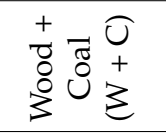 } & willows + coal (I) & 16.2 & light grey & 450.3 & medium & 288.6 & little \\
\hline & acacia + coal (III) & 16.1 & light grey & 400.9 & little & 267.1 & little \\
\hline \multirow{3}{*}{ 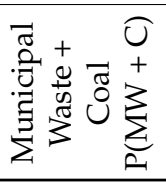 } & fabrics $+\operatorname{coal}(\mathrm{I})$ & 13.1 & dark ashen & 520.7 & medium & 310.7 & medium \\
\hline & mix of municipal waste + coal (III) & 15.1 & light grey & 581.7 & a lot & 350.1 & medium \\
\hline & PET drink bottle + coal (I) & 12.3 & very dark ashen & 580.3 & a lot & 323.3 & medium \\
\hline
\end{tabular}

${ }^{*}$ The amount of ash: little $(<10 \%$ of the primary material), medium $(10-20 \%$ of the primary material), a lot ( $>20 \%$ of the primary material). 


\subsection{Determination of Physical and Chemical Parameters}

\subsubsection{Constant Weight of Ashes}

During the first stage of the study, free water was removed from the ash samples. For that purpose, $100 \mathrm{~g}$ samples of fresh ash were weighed out and placed in a dryer for $2 \mathrm{~h}$ at $105^{\circ} \mathrm{C}$. After this time, the samples were removed and re-weighed. This was done until subsequent measurements did not differ by more than $0.001 \mathrm{~g}$.

\subsubsection{Preparation of Aqueous Extracts}

A $100 \mathrm{~g}$ portion was weighed out from each of the dried ash samples and mixed with $1000 \mathrm{~mL}$ of distilled water. Next, the mixtures were centrifuged for $2 \mathrm{~h}\left(22^{\circ} \mathrm{C}, 250 \mathrm{rpm}\right)$, and when the suspension stabilised, the liquid was decanted and filtered [29].

\subsubsection{Determination of $\mathrm{Cl}$ Content}

Chloride concentration was determined using Mohr's method. The reaction of chlorides with ions of silver leads to the formation of non-soluble silver chloride precipitated quantitatively. The introduction of a small excess of silver ions in the presence of chromate ions as an indicator produced a red-brown colour of silver chromate. The reaction indicates the end point of titration. Maintaining $\mathrm{pH}$ of 5-9.5 during the titration process allows precipitate formation. To determine the chloride content in aqueous extracts of ashes, $50 \mathrm{~cm}^{3}$ of clear extract was collected from each sample and placed in a conical flask. Then, $1 \mathrm{~cm}^{3}$ of potassium chromate solution $\left(\mathrm{K}_{2} \mathrm{CrO}_{4}\right)$ was added as an indicator. Next, drops of silver nitrate $\left(\mathrm{AgNO}_{3}\right)$ were added until the colour changed from yellow to red-brown. Titration was carried out in 5 repetitions.

\subsubsection{Determination of $\mathrm{SO}_{4}^{2}$ Content}

Sulphate concentration was determined using the gravimetric method. The reaction of sulphates with barium ions leads to the formation of non-soluble barium sulphate precipitated quantitatively. Low $\mathrm{pH}$ during the reaction allows for precipitate formation. For that purpose, $40 \mathrm{~cm}^{3}$ of clear ash extract was collected into a beaker and mixed with $60 \mathrm{~cm}^{3}$ of distilled water. The beakers with the mixtures were placed in a water bath. Then, $2 \mathrm{~cm}^{3}$ of $\mathrm{HCl}$ solution was added to each of them. Next, $10 \mathrm{~cm}^{3}$ of barium chloride $\left(\mathrm{BaCl}_{2}\right)$ was slowly added to the heated samples. Each solution was cooled down and then filtered through a previously weighted and moistened filter paper. After filtration, the filter papers were rinsed with distilled water to remove an excess of chlorides from the precipitate. Next, the filter papers were placed in a dryer, and after drying and cooling, they were weighted.

\subsubsection{Determination of $\mathrm{PO}_{4}{ }^{3-}$ Content}

The last of the anions analysed were phosphates, whose concentration was determined using the colourimetric method. In this technique, yellow phosphomolybdic acid $\left(\mathrm{H}_{7}(\mathrm{P}) \mathrm{MoO}_{2}\left(\mathrm{O}_{4}\right)_{6}\right)$ forms in acidic solution; then, it is reduced by tin (II) chloride to form a complex compound-molybdenum blue of intense blue colour, which is proportional to the content of orthophosphates.

For that purpose, $1.0 \mathrm{~g}$ of each type of ash was weighed out and mixed with $25 \mathrm{~cm}^{3}$ of concentrated hydrochloric acid $(37 \% \mathrm{HCl})$ and 5-6 drops of concentrated nitric acid $(65 \%$ $\mathrm{HNO}_{3}$ ). Then, distilled water was added up to the volume of $50 \mathrm{~cm}^{3}$. The beakers were covered and heated for $20 \mathrm{~min}$ until boiling. After cooling, insoluble parts were filtered into a $100 \mathrm{~cm}^{3}$ volumetric flask, and the precipitate on the filter paper was thoroughly rinsed with distilled water. The volumetric flask was filled up with distilled water, and then, $1-2 \mathrm{~cm}^{3}$ of the solution was placed in another $100 \mathrm{~cm}^{3}$ volumetric flask. Then, the following substances were added to that flask: $20 \mathrm{~cm}^{3}$ of distilled water, $2 \mathrm{~cm}^{3}$ of $10 \%$ ammonium heptamolybdate solution $\left.\left(\mathrm{NH}_{4}\right)_{6} \mathrm{Mo}_{7} \mathrm{O}_{24}\right)$, and 2 drops of saturated solution of tin(II) chloride $\left(\mathrm{SnCl}_{2}\right)$. Then, the flask was filled with distilled water up to $100 \mathrm{~cm}^{3}$. The absorption was measured using a UV-Vis, model Camspec/M501 Single Beam spectropho- 
tometer (Spectronic Camspec Ltd, Garforth, UK). Measurement precision for chlorides and sulphates was $0.01 \mathrm{mg} / \mathrm{dm}^{3}$, and for phosphates, it was $0.001 \mathrm{mg} / \mathrm{dm}^{3}$.

\section{Results and Discussion}

\subsection{The Amount of Ashes and the Type of Fuel and Waste Used in the Combustion Process}

The analysis of the 23 ash samples obtained involved the assessment of the following properties: the amount of ash generated during the combustion process, its colour, and the amount of non-combusted material (Table 1). The ashes did not differ much in terms of colour, which mostly comprised shades of grey. Black-grey colour of ashes was observed in the case of the following primary materials: ash, straw, sawdust, and diapers. Dark grey ashes were obtained after the combustion of willow, plywood, and the mix of textiles and hard coal. The rest of the samples were predominantly light grey (Table 1). To assess the amount of ash and non-combusted material, the following indicator was used: if the amount of ash generated was lower than $10 \%$ of the volume of the primary material, then this amount was considered small; if the amount of ash was $10-20 \%$ of the volume of primary material, it was considered moderate; and if the amount was bigger than $20 \%$ of the volume of primary material, it was classified as large. A small amount of ash (which is very desired) was observed after combusting: acacia wood, coal I, coal pellets, walnuts, sawdust, and the mix of acacia + coal III, and ash + coal III. A moderate amount of ash was obtained after combusting: ash wood, black elder wood, coal III, peat, paper and cardboard, plywood, the mix of willow wood + coal I, and the mix of textiles + coal I. As for the other samples analysed, the amount of ash was large. With regard to the third indicator - the amount of non-combusted material — a small (desired) amount was observed after combusting black elder wood, acacia wood, all types of coal, walnuts, paper and cardboard, plywood, and all mixes of wood and coal. A large amount of non-combusted primary material was found for the samples of ash wood, straw, sawdust, plastic-coated paper cartons, and diapers. With the other samples, the amount of non-combusted material was moderate, ranging between $10 \%$ and $20 \%$ of the initial amount.

Based on the analysis of macroscopic properties of the fuels and waste combusted, the following correlations were observed:

- Dark-coloured ashes were accompanied with a large amount of non-combusted material,

- Out of the wood species analysed, acacia displayed the best macroscopic parameters of ash, which means that little ash of light colour with a small amount of non-combusted material was generated,

- Out of the three types of coal combusted, coal I produced the smallest amount of ash and non-combusted material (despite having the largest fraction), which points to the high quality of this coal and a small amount of mineral substance in its composition,

- The addition of coal to wood results in a higher combustion temperature, and thus more effective material combustion; hence, a smaller amount of ash generated.

Additionally, observations of the combustion process yielded the following findings:

- Combustion time affected the amount of slag and ash generated. The longer the material stayed in the furnace chamber, the more efficiently it burnt, leaving less combustion products;

- Combustion temperature and rate varied greatly depending on the content of flammable substances;

- Excessive air supply accelerated combustion, but at the same time, it left certain amounts of material unburnt;

- Fragmented material burnt relatively faster, but at lower temperatures than largefraction material. 


\subsection{Environmental Threats and Possibilities of Ash Reuse}

\subsection{1. $\mathrm{Cl}^{-}$}

Concentrations of chloride anions in the ash aqueous extracts analysed displayed high variability and dispersion. The maximum concentration of $3049.6 \mathrm{mg} / \mathrm{dm}^{3}$ was determined for ash generated after coal III combustion (from Podkarpacie), whereas the lowest chloride concentration, $21.3 \mathrm{mg} / \mathrm{dm}^{3}$, was found in aqueous extract of ash produced from sawdust combustion. The average concentration (Av, arithmetic average) for all the samples analysed was $736.3 \mathrm{mg} / \mathrm{dm}^{3}$, and standard deviation (SD) from the average value was $693.8 \mathrm{mg} / \mathrm{dm}^{3}$, which confirms the high dispersion of the results.

The analysis of the average chloride concentrations for individual groups of ashes yielded the following descending order (Av for the entire group in $\mathrm{mg} / \mathrm{dm}^{3}$ provided in brackets): ashes from the mix of wood and coal (1002.3) > ashes from wood (934.7) > ashes from coals (909.5) $>$ ashes from the mix of municipal waste and coals $(602.8)>$ ashes from alternative fuels (521.3) > ashes from municipal waste (430.8). However, the large standard error (144.7) confirms the high variability of the results and thus measurement inaccuracy when using the arithmetic average (Table 2). Therefore, it seems more appropriate to analyse the median (Me) as the average value. Based on Me, the descending sequence is slightly different (Me for the entire group in $\mathrm{mg} / \mathrm{dm}^{3}$ provided in brackets): ashes from combusting the mix of wood and coal (1000.3) $>$ ashes from wood (985.8) $>$ ashes from municipal waste (468.0) $>$ ashes from alternative fuels $(400.7)>$ ashes from the mix of municipal waste and coals (361.7) $>$ ashes from coals (276.6). Having compared the Av and Me calculated, it was concluded that these values were comparable only in the case of ashes from wood, municipal waste, and mixes of coal and wood. For the other groups, medians were lower: from $20 \%$ (alternative fuels) to over $300 \%$ (coals). This shows that the parameter analysed varied greatly nearly in all the groups studied.

Table 2. Statistical parameters for chloride leaching from ashes.

\begin{tabular}{|c|c|c|c|c|c|c|}
\hline \multicolumn{2}{|r|}{ Sample } & \multicolumn{4}{|c|}{$\mathrm{Cl}^{-}\left[\mathrm{mg} / \mathrm{dm}^{3}\right]$} & \multirow{2}{*}{$\begin{array}{c}\mathrm{Cl}^{-}[\mathrm{mg} / \mathrm{kg}] \\
\\
9347.2^{\mathrm{b}} \pm 4648.1^{\mathrm{c}} \\
9858.7^{\mathrm{d}}\end{array}$} \\
\hline wood & $\begin{array}{c}\text { ash } \\
\text { black elderberry } \\
\text { acacia } \\
\text { willows } \\
\text { acacia + elderberry + ash + willows }\end{array}$ & $\begin{array}{l}\text { IV a } \\
\text { V } \\
\text { V } \\
\text { V } \\
\text { V }\end{array}$ & $\begin{array}{c}404 \\
510 \\
985 \\
1064 \\
1709\end{array}$ & $\begin{array}{c}934.7^{b} \pm 464.8^{c} \\
985.8^{d}\end{array}$ & $\begin{array}{c}4039 \\
5109 \\
9857 \\
10,642 \\
1709\end{array}$ & \\
\hline coal & $\begin{array}{c}\text { coal (I) } \\
\text { coal (II) } \\
\text { coal (III) } \\
\text { coal pellets (ekogroszek) }\end{array}$ & $\begin{array}{l}\text { II } \\
\text { IV } \\
\text { V } \\
\text { I }\end{array}$ & $\begin{array}{c}128 \\
425 \\
304 \\
35\end{array}$ & $\begin{array}{c}909.5 \pm 1243.9 \\
276.6\end{array}$ & $\begin{array}{c}1277 \\
42,585 \\
30,485 \\
354\end{array}$ & $\begin{array}{c}9095.1 \pm 12439.4 \\
2766.5\end{array}$ \\
\hline alternative fuels & $\begin{array}{l}\text { straw } \\
\text { peat } \\
\text { nuts } \\
\text { sawdust }\end{array}$ & $\begin{array}{l}\text { V } \\
\text { IV } \\
\text { IV } \\
\text { I }\end{array}$ & $\begin{array}{c}1262 \\
312 \\
489 \\
21\end{array}$ & $\begin{array}{c}521.3 \pm 459.4 \\
400.7\end{array}$ & $\begin{array}{c}12,629 \\
7866 \\
4901 \\
1063\end{array}$ & $\begin{array}{c}5213.7 \pm 4594.2 \\
4007.4\end{array}$ \\
\hline municipal waste & $\begin{array}{l}\text { paper and cardboard } \\
\text { plywood } \\
\text { tetrapaks } \\
\text { diapers }\end{array}$ & $\begin{array}{l}\text { IV } \\
\text { V } \\
\text { III } \\
\text { V }\end{array}$ & $\begin{array}{l}354 \\
617 \\
170 \\
581\end{array}$ & $\begin{array}{c}430.8 \pm 181.1 \\
468.0\end{array}$ & $\begin{array}{c}3541 \\
6164 \\
1701 \\
29,118\end{array}$ & $\begin{array}{c}4308.5 \pm 1811.6 \\
1810.9\end{array}$ \\
\hline wood + coal & $\begin{array}{l}\text { ash + coal (III) } \\
\text { willows + coal (I) } \\
\text { acacia + coal (III) }\end{array}$ & $\begin{array}{l}\mathrm{V} \\
\mathrm{IV} \\
\mathrm{V}\end{array}$ & $\begin{array}{c}1000 \\
404 \\
1603\end{array}$ & $\begin{array}{c}1002.3 \pm 489.3 \\
1000.3\end{array}$ & $\begin{array}{c}9992 \\
4043 \\
16,031\end{array}$ & $\begin{array}{c}1023.7 \pm 4893.3 \\
4893.7\end{array}$ \\
\hline $\begin{array}{l}\text { municipal waste }+ \\
\text { coal }\end{array}$ & $\begin{array}{c}\text { fabrics + coal (I) } \\
\text { mix of municipal waste }+ \text { coal }(\mathrm{III}) \\
\text { PET drink bottle }+ \text { coal }(\mathrm{I})\end{array}$ & $\begin{array}{l}\text { IV } \\
\text { V } \\
\text { IV }\end{array}$ & $\begin{array}{c}362 \\
1170 \\
276\end{array}$ & $\begin{array}{c}602.8 \pm 402.7 \\
361.7\end{array}$ & $\begin{array}{c}3615 \\
11,688 \\
2763\end{array}$ & $\begin{array}{c}6028.2 \pm 4027.1 \\
3617.0\end{array}$ \\
\hline \multicolumn{7}{|c|}{ for all ash samples $(n=23)$} \\
\hline & $\begin{array}{c}\text { Min.-Max. } \\
\text { Av. } \pm \text { SD } \\
\text { Me } \\
\text { V [\%] }\end{array}$ & & & $\begin{array}{l}3049.6 \\
\pm 693.8 \\
9.3 \\
4.2\end{array}$ & & $\begin{array}{c}213.8-30496.1 \\
7363.5 \pm 6938.4 \\
4893.8 \\
94.7\end{array}$ \\
\hline
\end{tabular}

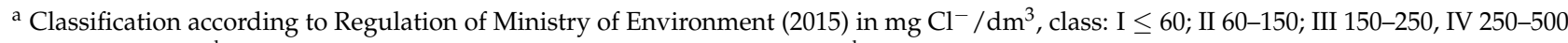

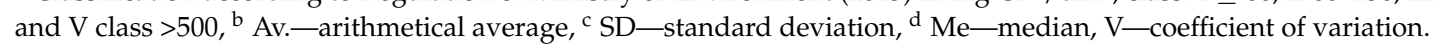

The lowest chloride leaching level was observed in ashes obtained after combusting municipal waste and most of the coals tested. Moreover, the mix of the two materials 
produced a result comparable with $\mathrm{Cl}^{-}$concentrations found in ashes from alternative fuel combustion. The worst situation (the highest concentrations) was observed in the case of ashes generated from combusting wood and wood mixed with coal, although one of the lowest concentrations of chlorides $\left(35.5 \mathrm{mg} / \mathrm{dm}^{3}\right)$ was recorded for coal pellets. However, it was also in this group where the highest $\mathrm{Cl}^{-}$leaching level was observed $\left(3049.6 \mathrm{mg} / \mathrm{dm}^{3}\right)$ - these were ashes produced from fine-sized coal from Podkarpacie. Water leaching of chlorides is of great significance when assessing the risk of chloride penetration into surface and ground water [13,30]. According to Kabata-Pendias and Pendias [31], natural concentrations of chlorides in river water are about $8 \mathrm{mg} / \mathrm{dm}^{3}$, and the background for ground water is even lower and amounts to merely $0.2 \mathrm{mg} / \mathrm{dm}^{3}$. When classifying the aqueous extracts in terms of the risk associated with chloride ion leaching to ground water (Table 2), it was found that the leachates of ashes from wood combustion pose the greatest threat and thus need to be allocated to class V (in accordance with the Regulation of the Minister of the Environment [32]). Ashes from coal, mixes of coal with wood, and coal with municipal waste represent class IV, whereas leaching of chlorides from ashes generated after municipal waste combustion represents pollution level categorised as class III. To conclude, the amounts of chlorides leached from the ashes were many times higher than those suggested as the geochemical background for this anion. Thus, the ashes studied should be regarded as a material posing a great threat to the aquatic environment. Indeed, chlorides are found in all living organisms, where they play an important role, especially in maintaining proper osmotic pressure. They are also the basic component of physiological fluids in the human body. However, the allowable levels of $\mathrm{Cl}^{-}$ in water intended for human consumption [33] range between 0 and $250 \mathrm{mg} / \mathrm{dm}^{3}$. The chloride anion is regarded as a fundamental element in the environment, where it remains unchanged, either solved in water or in the form of easily soluble salts. It does not form insoluble compounds and is not absorbed by the soil material or by bottom sediments in surface water. A natural source of chlorides is the weathering of silicate rocks and leaching of various salt deposits containing this compound [15].

The content of chlorides in soils varies greatly depending on the distance from the shoreline, and it usually ranges between 115 and $1000 \mathrm{mg} / \mathrm{kg}$ [30]. In terms of the amount of chlorides contained in ashes by weight $(213.8-30496 \mathrm{mg} / \mathrm{kg}, \mathrm{Me}=4893.8 \mathrm{mg} / \mathrm{kg})$, these materials must be considered a significant threat to the soil environment (Table 2).

Regarding ash storage at landfills [27], these ashes should be stored at landfills for waste other than inert and hazardous waste (for which the recommended $\mathrm{Cl}^{-}$content range is $800-25,000 \mathrm{mg} / \mathrm{kg}$ ), except for the ashes formed after burning poor-quality coal, where the amount of chlorides by weight exceeded the upper limit.

When analysing the content of chlorides in the ashes tested with regard to their reuse, the author of the present paper referred to a standard [34], which defines the requirements for chemical composition of ashes that are used as an additive to concrete. According to this standard, the maximum content of chlorides in ash aqueous extract should be $\geq 0.1 \%$. Seven out of 23 of the ash samples analysed did not meet this requirement. These were ashes generated from the combustion of willow, mix of wood from all 4 species analysed, coal III and any material added to it (ash, acacia, and mixed fraction of municipal waste), and ash from straw (Table 2).

Horák et al. [19] obtained similar data for ashes after combusting various fractions of municipal waste, indicating that in the case of floor coverings mixed with dry beech, the content of chlorides may reach even up to $191,000 \mathrm{mg} / \mathrm{kg}$. A high concentration of chlorine (4.7 wt \%) in biomass bottom ash was also observed by Suárez-Macías et al. [23] and Link et al. [21]. In water extracts, the concentration of chloride was considerably lower and amounted to $134 \mathrm{mg} / \mathrm{kg}$ on average [23].

\subsection{2. $\mathrm{SO}_{4}{ }^{2-}$}

Concentrations of sulphates in aqueous extracts of the ashes analysed display a high range $\left(12.2-3059 \mathrm{mg} / \mathrm{dm}^{3}\right)$. The lowest concentration of $\mathrm{SO}_{4}{ }^{2-}$ was found in aqueous 
extract of ashes from plastic-coated paper cartons, and the highest was found in ashes from willow wood with the addition of coal I (from coal storage site in Małopolska). For all the samples analysed, the arithmetic average was $1162.6 \mathrm{mg} / \mathrm{dm}^{3}$, and SD was $839.7 \mathrm{mg} / \mathrm{dm}^{3}$ (Table 3). The variation coefficient (72.2\%) and standard error (175.1), which determines the inaccuracy of describing the entire set of $\mathrm{SO}_{4}{ }^{2-}$ concentration results using Av, were also high.

Table 3. Statistical parameters for water leaching of sulphide from ashes.

\begin{tabular}{|c|c|c|c|c|c|c|}
\hline \multicolumn{2}{|r|}{ Sample } & \multicolumn{4}{|c|}{$\begin{array}{c}\mathrm{SO}_{4} \\
{\left[\mathrm{mg} / \mathrm{dm}^{3}\right]}\end{array}$} & $\begin{array}{c}\mathrm{SO}_{4} \\
{[\mathrm{mg} / \mathrm{kg}]}\end{array}$ \\
\hline \multirow{5}{*}{ wood } & \multirow{5}{*}{$\begin{array}{c}\text { ash } \\
\text { black elderberry } \\
\text { acacia } \\
\text { willows } \\
\text { acacia + elderberry + ash + } \\
\text { willows }\end{array}$} & $\mathrm{V}^{\mathrm{a}}$ & 848 & \multirow{5}{*}{$\begin{array}{c}1762.1^{b} \pm 616.1^{c} \\
1678.4^{d}\end{array}$} & 16,946 & \multirow{5}{*}{$\begin{array}{c}35,168.3^{b} \pm 12,313.9^{c} \\
33,509.5^{d}\end{array}$} \\
\hline & & $\mathrm{V}$ & 1678 & & 33,509 & \\
\hline & & $\mathrm{V}$ & 1400 & & 27,858 & \\
\hline & & $\mathrm{V}$ & 2455 & & 49,125 & \\
\hline & & $\mathrm{V}$ & 2428 & & 48,402 & \\
\hline \multirow{4}{*}{ coal } & $\operatorname{coal}(\mathrm{I})$ & $\mathrm{V}$ & 1056 & \multirow{4}{*}{$\begin{array}{c}1269.5 \pm 383.7 \\
1457.3\end{array}$} & 21,118 & \multirow{4}{*}{$\begin{array}{c}25,329.2 \pm 7646.4 \\
29,106.8\end{array}$} \\
\hline & coal (II) & $\mathrm{V}$ & 1793 & & 35,712 & \\
\hline & $\operatorname{coal}(\mathrm{III})$ & $\mathrm{V}$ & 1457 & & 29,107 & \\
\hline & coal pellets (ekogroszek) & $\mathrm{V}$ & 772 & & 15,379 & \\
\hline \multirow{4}{*}{ alternative fuels } & straw & $\mathrm{V}$ & 894 & \multirow{4}{*}{$\begin{array}{c}460.5 \pm 316.1 \\
450.0\end{array}$} & 17,867 & \multirow{4}{*}{$\begin{array}{c}9225.1 \pm 6308.6 \\
9035.1\end{array}$} \\
\hline & peat & IV & 307 & & 6190 & \\
\hline & nuts & $\mathrm{V}$ & 593 & & 11,879 & \\
\hline & sawdust & I & 48 & & 963 & \\
\hline \multirow{4}{*}{ municipal waste } & paper and cardboard & I & 21 & \multirow{4}{*}{$\begin{array}{c}250.5 \pm 265.8 \\
163.3\end{array}$} & 428 & \multirow{4}{*}{$\begin{array}{c}4995.0 \pm 5300.8 \\
3253.7\end{array}$} \\
\hline & plywood & $\mathrm{V}$ & 663 & & 13,228 & \\
\hline & tetrapaks & $\mathrm{I}$ & 12 & & 244 & \\
\hline & diapers & IV & 305 & & 6079 & \\
\hline \multirow{3}{*}{ wood + coal } & ash + coal (III) & $\mathrm{V}$ & 1967 & \multirow{3}{*}{$\begin{array}{c}2335.5 \pm 511.8 \\
1980.1\end{array}$} & 39,296 & \multirow{3}{*}{$\begin{array}{c}46,630.9 \pm 10,266.6 \\
39,446.4\end{array}$} \\
\hline & willows + coal (I) & $\mathrm{V}$ & 3059 & & 61,149 & \\
\hline & acacia + coal (III) & $\mathrm{V}$ & 1980 & & 39,446 & \\
\hline \multirow{3}{*}{$\begin{array}{l}\text { municipal waste }+ \\
\text { coal }\end{array}$} & fabrics $+\operatorname{coal}(\mathrm{I})$ & $\mathrm{V}$ & 1163 & \multirow{3}{*}{$\begin{array}{c}999.5 \pm 254.2 \\
1163.4\end{array}$} & 23,308 & \multirow{3}{*}{$\begin{array}{c}20,006.7 \pm 5105.7 \\
23,308.3\end{array}$} \\
\hline & mix of municipal waste + coal (III) & $\mathrm{V}$ & 1195 & & 23,917 & \\
\hline & PET drink bottle + coal $(\mathrm{I})$ & $\mathrm{V}$ & 641 & & 12,794 & \\
\hline \multicolumn{7}{|c|}{ for all samples $(n=23)$} \\
\hline & Min.-Max. & & & -3059.2 & & 244.1-61,149.8 \\
\hline & Av. \pm SD & & & $6 \pm 839.7$ & & $23,215.3 \pm 16,762.8$ \\
\hline & $\mathrm{Me}$ & & & 055.7 & & $21,118.3$ \\
\hline & $\mathrm{V}[\%]$ & & & 72.2 & & 72.2 \\
\hline
\end{tabular}

${ }^{a}$ Classification according Regulation of Ministry of Environment (2015), in $\mathrm{mg} \mathrm{Cl}^{-} / \mathrm{dm}^{3}$, class: I $\leq 60$; II 60-150; III 150-250, IV 250-500 and V class $>500,{ }^{b}$ Av.-arithmetical average, ${ }^{c}$ SD—-standard deviation, ${ }^{d} \mathrm{Me}$-median, V-coefficient of variation.

Assuming the division of the ashes tested into groups based on primary materials, and using the average value (Av or $\mathrm{Me}$ ) as an indicator calculated for individual groups to assess sulphate leaching, the following descending order was obtained (with average values, here Me in $\mathrm{mg} / \mathrm{dm}^{3}$ in brackets): ashes from the mix of wood and coals (1980) > ashes from wood (1678) > ashes from coals (1257) > ashes from the mix of municipal waste and coals (1163) > ashes from alternative fuels (450) $>$ ashes from municipal waste (163). It can be seen that the highest and lowest average concentrations of $\mathrm{SO}_{4}{ }^{2-}$ determined in aqueous extracts can differ over 10 times between individual groups.

In rivers and lakes, $\mathrm{SO}_{4}{ }^{2-}$ concentrations are about $16 \mathrm{mg} / \mathrm{dm}^{3}$, whereas in sea water, the amount of this anion can reach even $2700 \mathrm{mg} / \mathrm{dm}^{3}$. Sulphate-free natural waters are extremely rare. These are mostly waters associated with petroleum deposits, where a biochemical reduction of sulphates to hydrogen sulphide takes place. In ground water, similarly to chlorides, the following concentrations of $\mathrm{SO}_{4}{ }^{2-}$ are allowable for five contamination classes (in $\mathrm{mg} / \mathrm{dm}^{3}$ ): class I—60, class II-150, class III—250, class IV—500, and class $V>500$ [32]. In light of these values, a vast majority of aqueous extracts of the ashes studied exceeded the limits for classes I-IV and thus had to be assigned to class V 
(Table 3). The only exception were aqueous extracts of ashes from peat and diapers, where the concentration of $\mathrm{SO}_{4}{ }^{2-}$ was $305-306 \mathrm{mg} / \mathrm{dm}^{3}$, falling into class IV, and ashes from sawdust, paper and cardboard, and plastic-coated paper cartons, where $\mathrm{SO}_{4}{ }^{2-}$ levels were below $50 \mathrm{mg} / \mathrm{dm}^{3}$, falling into class I (Table 3).

Sulphates are regarded as one of the least toxic anions, although their high concentrations cause dehydration and irritation of the gastrointestinal tract. The levels of $\mathrm{SO}_{4}{ }^{2-}$ in water intended for human consumption [33] range between 0 and $250 \mathrm{mg} / \mathrm{dm}^{3}$. Sulphate anions commonly occur in natural waters. They enter these waters as a result of leaching form rocks and soils, precipitation, biochemical oxidation of other forms of sulphur, and together with municipal and industrial waste water [11]. Mining water is also an important source of sulphates. These compounds can also enter water from organic sulphur oxidation products and volcanic gases. The anions can also be derived from minerals, e.g., salt, and oxidation of heavy metal sulphides. Surface water can be contaminated with pollutants from industrial waste water containing sulphates from the production of e.g., sulphuric acid, fertilisers, etc. [3]

When assessing the risk posed by $\mathrm{SO}_{4}{ }^{2-}$ leached from the ashes studied to the soil environment, the following limit values, determined for IV classes of soil contamination with sulphur compounds, were adopted (in $\mathrm{mg} \mathrm{S}^{-S_{4}} / \mathrm{kg}$ ): class I <1500, class II-16002500, class III-2600-3500, and class IV >3500 [35]. Out of all ash samples analysed, as many as 18 were heavily contaminated with sulphur (class IV), two (i.e., ash from peat and diapers) displayed a moderate content of sulphur (class III), and three (ash from sawdust, paper, and cardboard, and plastic-coated paper cartons) had a very low content of sulphur compounds (class I).

Regarding ash storage at landfills $[27,36]$, ashes generated from the combustion of alternative fuels and municipal waste should be stored at landfills for waste other than inert and hazardous waste (for which the recommended $\mathrm{SO}_{4}{ }^{2-}$ content range is $1000-20,000 \mathrm{mg} / \mathrm{kg}$ ). On the other hand, ashes formed after burning poor-quality coal, wood, and mixes of the two should be stored at hazardous waste landfills.

The PN-EN 450-1 standard [37], regulating the potential use of ashes as an additive to concrete, indicates that in the case of sulphur compounds, their amount cannot exceed 3\% of the total weight of ashes. None of the ashes generated from the combustion of wood and coal mixes met this criterion, which was also the case with ashes from coal II, black elder, willow, and the mix of all tree species analysed in this study.

Apart from the type of fuel combusted, another important issue in the analysis of chemical composition of ashes is the impact of the type of furnace and the way of coal feeding, which was studied by Wasilewski and Radko [38]. These authors analysed one type of coal combusted in different types of heating devices (grate hearth, stoker-fired boiler with manual fuel feeding and bottom combustion, retort boiler with automatic fuel feeding, and grate furnace). The content of $\mathrm{Cl}^{-}$ranged from 15.7 to $63.2 \mathrm{mg} / \mathrm{kg}$, and in the case of $\mathrm{SO}_{4}{ }^{2-}$, the differences were even greater, ranging from 1210 to $15,430 \mathrm{mg} / \mathrm{kg}$.

A high concentration of sulphur compounds (6.43 wt \% and $3.3 \mathrm{wt} \%$ ) in biomass bottom ash was also recorded by Suárez-Macías et al. [23] and Link et al. [21], respectively. These findings are perfectly in line with our results. On the other hand, in a study by Monedero et al. [22], the concentration of sulphur in the ash from willow, poplar and black locust was $0.05-0.03$ wt \%, which is lower than the values obtained in our study, especially in the case of willow. These differences may be due to the moisture of wood as well as the differing conditions of tree growth and their exposure to atmospherically transported pollutants.

\subsection{3. $\mathrm{PO}_{4}{ }^{3-}$}

Phosphate concentrations in aqueous extracts of the ashes analysed ranged from 0.01 to $67.22 \mathrm{mg} / \mathrm{dm}^{3}$ (Table 4 ). Extreme concentrations (minimum and maximum) were found in the samples of ash generated from the combustion of plastic-coated paper cartons and diapers, respectively. 
Table 4. Statistical parameters for water leaching of phosphates from ashes.

\begin{tabular}{|c|c|c|c|c|c|c|}
\hline \multicolumn{2}{|c|}{ Sample } & \multicolumn{4}{|c|}{$\begin{array}{c}\mathrm{PO}_{4} \\
{\left[\mathrm{mg} / \mathrm{dm}^{3}\right]}\end{array}$} & \multirow[t]{2}{*}{$\begin{array}{c}\mathrm{PO}_{4} \\
{[\mathrm{mg} / \mathrm{kg}]}\end{array}$} \\
\hline \multirow{5}{*}{ wood } & ash & $\mathrm{V}^{\mathrm{a}}$ & 5.8 & \multirow{4}{*}{$\begin{array}{c}2.3^{b} \pm 2.0^{c} \\
1.2^{d}\end{array}$} & 116.8 & \\
\hline & black elderberry & IV & 3.2 & & 63.7 & \multirow{4}{*}{$\begin{array}{c}45.6^{b} \pm 40.8^{c} \\
23.0^{d}\end{array}$} \\
\hline & acacia & IV & 1.1 & & 22.1 & \\
\hline & willows & $\mathrm{I}$ & 0.1 & & 2.7 & \\
\hline & $\begin{array}{c}\text { acacia }+ \\
\text { elderberry }+ \text { ash }+ \\
\text { willows }\end{array}$ & IV & 1.2 & & 23.0 & \\
\hline \multirow{4}{*}{ coal } & $\operatorname{coal}(\mathrm{I})$ & $\mathrm{I}$ & 0.1 & \multirow{4}{*}{$\begin{array}{c}0.4 \pm 0.5 \\
0.1\end{array}$} & 3.0 & \multirow{4}{*}{$\begin{array}{c}8.0 \pm 10.1 \\
3.0\end{array}$} \\
\hline & coal (II) & $\mathrm{I}$ & 0.1 & & 2.5 & \\
\hline & $\operatorname{coal}(\mathrm{III})$ & IV & 1.2 & & 2.8 & \\
\hline & coal (ekogroszek) & $\mathrm{I}$ & 0.1 & & 23.8 & \\
\hline \multirow{4}{*}{ alternative fuels } & straw & IV & 4.9 & \multirow{4}{*}{$\begin{array}{c}7.4 \pm 7.1 \\
5.1\end{array}$} & 98.6 & \multirow{4}{*}{$\begin{array}{c}149.0 \pm 142.9 \\
101.4\end{array}$} \\
\hline & peat & $\mathrm{I}$ & 0.3 & & 6.1 & \\
\hline & nuts & $\mathrm{V}$ & 19.3 & & 387.2 & \\
\hline & sawdust & $\mathrm{V}$ & 5.2 & & 104.2 & \\
\hline \multirow{4}{*}{ municipal waste } & $\begin{array}{l}\text { paper and } \\
\text { cardboard }\end{array}$ & $\mathrm{I}$ & 0.1 & \multirow{4}{*}{$\begin{array}{c}16.9 \pm 29.0 \\
0.3\end{array}$} & 1.7 & \multirow{4}{*}{$\begin{array}{c}337.5 \pm 578.5 \\
5.3\end{array}$} \\
\hline & plywood & $\mathrm{I}$ & 0.4 & & 8.8 & \\
\hline & tetrapaks & $\mathrm{I}$ & 0.01 & & 0.1 & \\
\hline & diapers & $\mathrm{V}$ & 67.2 & & 1339.4 & \\
\hline \multirow{3}{*}{ wood + coal } & ash + coal (III) & I & 0.2 & \multirow{3}{*}{$\begin{array}{c}0.1 \pm 0.1 \\
0.1\end{array}$} & 4.3 & \multirow{3}{*}{$\begin{array}{c}2.5 \pm 1.3 \\
2.2\end{array}$} \\
\hline & willows + coal (I) & I & 0.1 & & 2.2 & \\
\hline & acacia + coal (III) & I & 0.1 & & 1.1 & \\
\hline \multirow{3}{*}{$\begin{array}{l}\text { municipal waste }+ \\
\text { coal }\end{array}$} & fabrics + coal (I) & $\mathrm{I}$ & 0.2 & \multirow{3}{*}{$\begin{array}{c}0.1 \pm 0.01 \\
0.1\end{array}$} & 3.0 & \multirow{3}{*}{$\begin{array}{c}1.8 \pm 0.9 \\
1.3\end{array}$} \\
\hline & $\begin{array}{l}\text { mix of municipal } \\
\text { waste }+ \text { coal (III) }\end{array}$ & $\mathrm{I}$ & 0.1 & & 1.3 & \\
\hline & $\mathrm{PET}+\operatorname{coal}(\mathrm{I})$ & $\mathrm{I}$ & 0.1 & & 1.1 & \\
\hline \multirow{5}{*}{\multicolumn{2}{|c|}{$\begin{array}{c}\text { Min.-Max. } \\
\text { Av. } \pm \text { SD } \\
\text { Me } \\
\text { V [\%] }\end{array}$}} & \multicolumn{4}{|c|}{ for all samples $(n=23)$} & \\
\hline & & \multicolumn{4}{|c|}{$0.01-67.22$} & $0.1-1339.4$ \\
\hline & & \multicolumn{4}{|c|}{$4.8 \pm 14.2$} & $96.5 \pm 283.6$ \\
\hline & & \multicolumn{4}{|c|}{0.2} & 4.3 \\
\hline & & \multicolumn{4}{|c|}{294.4} & 293.9 \\
\hline
\end{tabular}

${ }^{a}$ Classification according Regulation of Ministry of Environment (2015), in mg/dm ${ }^{3}$, class: I and II $\leq 0.5$; III 0.5-1; IV 1-5 and V > 5,

b Av.-arithmetical average, ${ }^{c}$ SD—standard deviation, ${ }^{\mathrm{d}} \mathrm{Me}$-median, V-coefficient of variation.

The analysis of the results obtained for the entire set of samples and individual ash groups displayed high heterogeneity and variability of values. The arithmetic average for all 23 ash samples was $4.8 \mathrm{mg} / \mathrm{dm}^{3}$, whereas the median was merely $0.2 \mathrm{mg} / \mathrm{dm}^{3}$, which indicates that the concentrations of the compound analysed were largely similar to the lowest values in the range. This assumption was confirmed by the high value of the variance coefficient, which was $294.4 \%$ in relation to the average mentioned.

The amounts of phosphates were relatively low compared to the determined concentrations of chlorides and sulphates. Based on the median, the groups of ashes can be arranged in the following descending order (Me for individual groups in $\mathrm{mg} / \mathrm{dm}^{3}$ provided in brackets): ashes from alternative fuels (5.055) $>$ ashes from wood (1.153) > ashes from municipal waste $(0.263)>$ ashes from coals $(0.149)>$ ashes from the mix of wood and coals (0.111) > ashes from the mix of municipal waste and coals (0.067).

Concentrations of phosphates in contaminated ground and lake waters are quite low. They amount to $0.06-0.1 \mathrm{mg} / \mathrm{dm}^{3}(n=1483)$ for ground water absorbed by grasslands [39] and $0.03-0.2 \mathrm{mg} / \mathrm{dm}^{3}$ for lake water [40]. Sources of phosphorus compounds in water include natural weathering of phosphate minerals and economic human activity, i.e., substances from municipal and industrial waste water, comprising point sources of phosphates. Currently, more attention is being paid to the increase in the amount phosphorus used in large areas of land, especially in agriculture, as a significant source of surface water contamination, which to a large extent determines the eutrophication of surface water. When assessing the risk to the aqueous environment related to $\mathrm{PO}_{4}{ }^{3-}$ leaching from the ashes 
analysed, the author of the present study used limit values from five classes of ground water contamination [32], which are as follows (in $\mathrm{mg} / \mathrm{dm}^{3}$ ): class $\mathrm{I}<0.5$, class II-0.5, class III-1, class IV -5 , and class V $>5$. Aqueous extracts of ashes from the mixes of coals and wood, and mixed municipal waste did not exceed $0.5 \mathrm{mg} / \mathrm{dm}^{3}$, thus falling into class $\mathrm{I}$. Most of the aqueous extracts in the group of segregated municipal waste and coals also represented class I (Table 4 ). The exception was aqueous extract of ash from the combustion of diapers (with the highest concentration of phosphates, i.e., $67.22 \mathrm{mg} / \mathrm{dm}^{3}$ ) and extract of ash from coal III (assigned to class III). As expected, the highest concentrations of $\mathrm{PO}_{4}{ }^{3-}$ were found in aqueous extracts of ashes from wood (class IV and V), and in samples of alternative fuels (especially walnuts and sawdust). This is because phosphates are biogenic, and the share of phosphorus compounds in the chemical composition of plants may reach even 0.3 wt \%.

Soils have a limited ability to absorb phosphorus compounds, whose mobility in the soil profile is limited and occurs mainly with the downflow of infiltration water. The total phosphorus content in soils ranges between 500 and $800 \mathrm{mg} / \mathrm{kg}$, which to a large extent is determined by the type of bedrock and a number of physical, chemical, and topographic factors in a given area. The share of $\mathrm{PO}_{4}{ }^{3-}$ in the total anion content in soils does not exceed several percent. Pietrzak et al. [39] demonstrated that the content of phosphorus in soil aqueous extracts may range between 0.3 and $86.1 \mathrm{mg} / \mathrm{kg}$, and surface runoff can carry from 0.34 to $17.89 \mathrm{mg} \mathrm{PO}_{4} / \mathrm{dm}^{3}$. Annual amounts of phosphorus leached from mineral soils do not exceed $1 \mathrm{~kg} / \mathrm{ha}[39,41]$. Comparing these findings to the results of this study, it needs to be stated that the ashes formed after the combustion of wood, alternative fuels (especially walnuts and sawdust), and diapers may constitute a significant source of phosphates (phosphorus) in the soil environment.

Phosphate concentrations in ashes rarely appear in the literature. Link et al. [21] determined the content of $\mathrm{P}_{2} \mathrm{O}_{5}$ in various ashes obtained from biomass combustion. These values ranged from 1.5 to 3.0 wt \%, being considerably higher than our results. These differences may stem from the limited mobility of phosphorus compounds in the soil profile and possible geochemical anomalies occurring in individual habitats.

As for the potential reuse of ashes in the production of concrete and $\mathrm{PO}_{4}{ }^{3-}$ leachability, the PN-EN 450 standard [37]:

- Does not require the content of soluble phosphorus compounds to be determined in the case of ashes obtained after burning coal only, or

- Sets the maximum limit of $100 \mathrm{mg} / \mathrm{kg}$ in the case of ashes generated via co-combustion only.

Only two of the samples analysed (i.e., ashes from diapers and walnuts) did not fulfil these requirements.

\subsection{Correlations between Anions}

The first substantial observation was the lack of normal distribution of all three anions analysed and a large disproportion between the concentrations of leached chlorides (21.3-3049.6 mg/ $\left.\mathrm{dm}^{3}\right)$, sulphates (12.2-3059.2 mg/ $\left.\mathrm{dm}^{3}\right)$, and phosphates $\left(0.01-67.22 \mathrm{mg} / \mathrm{dm}^{3}\right)$ in aqueous extracts of the ashes analysed (Figure 2). Based on the independent-samples $t$-test, it was demonstrated that the differences between the concentrations of $\mathrm{Cl}^{-}, \mathrm{SO}_{4}{ }^{2-}$, and $\mathrm{PO}_{4}{ }^{3-}$ were statistically significant (at $p=0.01$ ). 


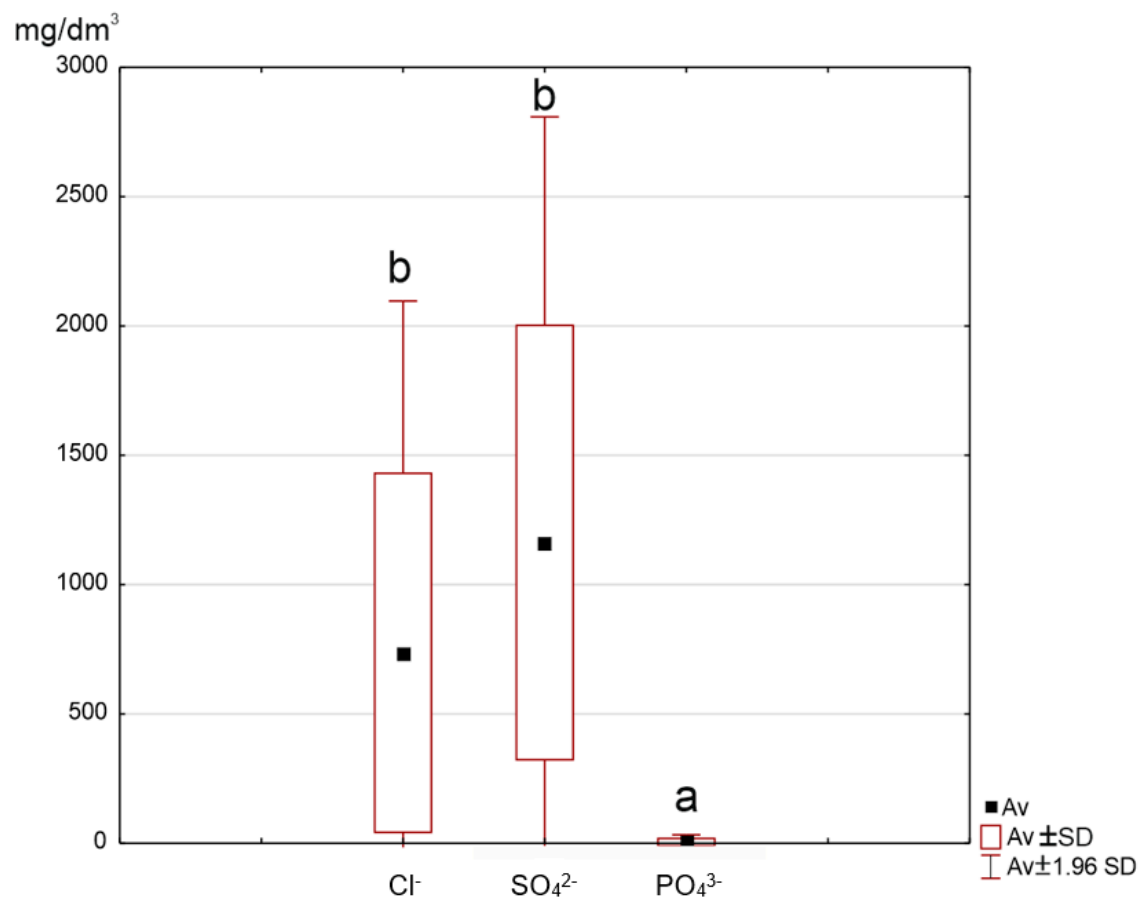

Figure 2. Boxplot for anions in ashes. Means marked with the same letter do not differ at $p=0.05$.

Cluster analysis was performed for $\mathrm{Cl}^{-}, \mathrm{SO}_{4}{ }^{2-}$ and $\mathrm{PO}_{4}{ }^{3-}$ concentrations, which allowed for separating data clusters and visualising correlations between them. Ward's minimum variance method was used, as it merges the data analysed and distinguishes clusters with minimum variance. The analysis of individual anion groups demonstrated a strong correlation between sulphate and chloride anions $\left(r^{2}=0.43\right)$, which was over 20 times stronger than the correlation between these two anions and phosphates (Figure 3A).
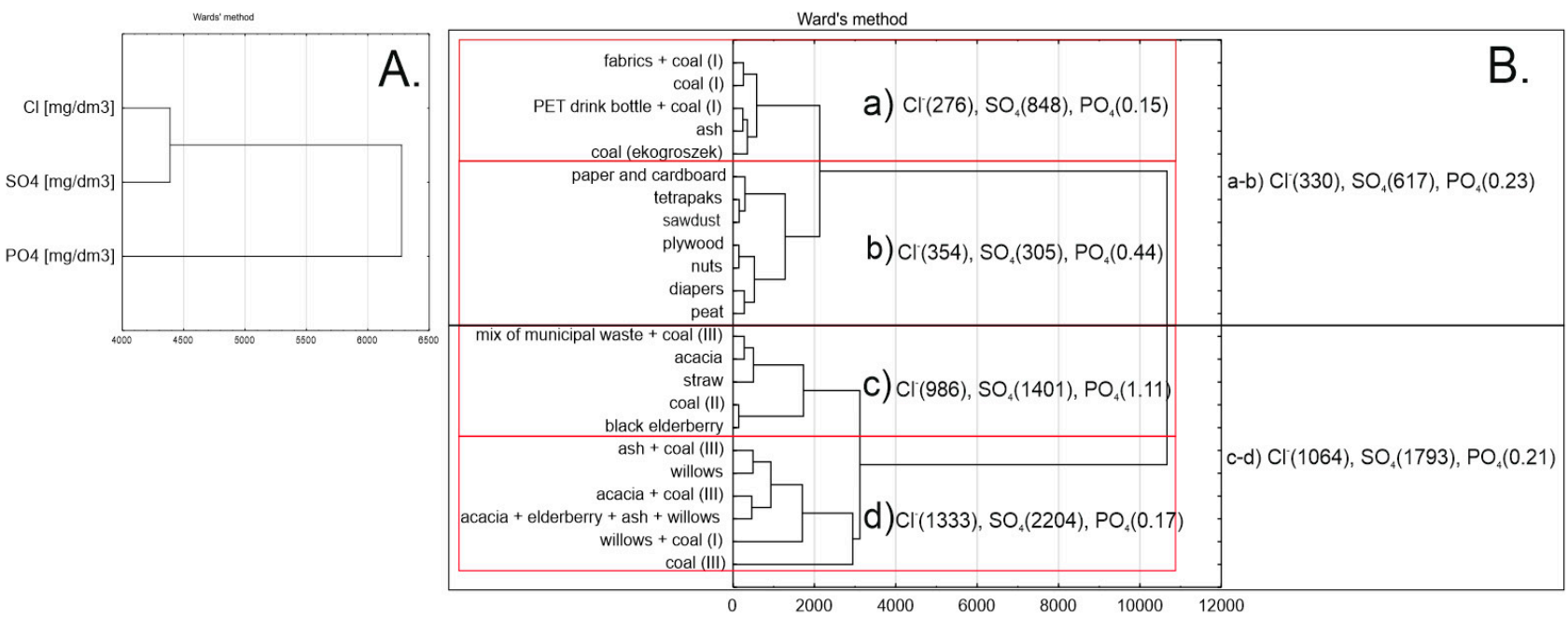

Figure 3. Dendrograms for ashes: (A) — for all determined anion groups, (B) — for all tested samples; the numbers in brackets relate to the median concentrations of that cluster.

The nature of this relationship may stem from similar concentrations of chlorides and sulphates and their comparable solubility in aqueous extracts. Sulphates and chlorides are very soluble in water, especially when they form compounds (salts) of mono- and divalent metal cations such as $\mathrm{Na}^{+}$or $\mathrm{Mg}^{2+}$. On the other hand, the solubility of phosphates is related to the subcategory they belong to: primary phosphates are easily soluble in water, 
but out of secondary and tertiary phosphates, only the salts of alkali metals (apart from lithium) and ammonium are water-soluble.

The analysis of correlations between individual cases, namely the 23 ash samples, allowed for distinguishing four $(\mathrm{a}-\mathrm{d})$ clusters (Figure 3B). Cluster $(a)$ included ashes from the combustion of coal I and mixes including this type of coal (textiles, PET bottles), ashes from coal pellets, and ash wood. The average concentrations of $\mathrm{Cl}^{-}, \mathrm{SO}_{4}{ }^{2-}$, and $\mathrm{PO}_{4}{ }^{3-}$ for this cluster of samples were $\left(\mathrm{Me}\right.$, in $\left.\mathrm{mg} / \mathrm{dm}^{3}\right) 276,848$, and 0.15 , respectively. In the case of chlorides and phosphates, these were the lowest values out of all Me calculated for individual clusters. Coal I was coarse and had a low content of chlorides and phosphates. Cluster $(b)$ generally comprised ashes from alternative fuels (sawdust, walnuts, peat) and municipal waste (paper and cardboard, plastic-coated paper cartons, plywood, diapers). The average concentrations of chlorides and phosphates were slightly higher than in the previous cluster, and they amounted to $\left(\mathrm{Me}, \mathrm{in} \mathrm{mg} / \mathrm{dm}^{3}\right)$ : 354 and 0.44 , respectively. However, the Me for sulphates was the lowest out of all four clusters- $-305 \mathrm{mg} / \mathrm{dm}^{3}$. The third cluster (c) included ashes from various primary materials: wood (acacia, black elder), alternative fuels (straw), coals (coal II), and the mix of municipal waste and coal III. This cluster displayed the highest average for phosphates $\left(\mathrm{Me}=1.11 \mathrm{mg} / \mathrm{dm}^{3}\right)$ and high average values for chlorides $\left(\mathrm{Me}=986 \mathrm{mg} / \mathrm{dm}^{3}\right)$ and sulphates $\left(\mathrm{Me}=1401 \mathrm{mg} / \mathrm{dm}^{3}\right)$. The last, fourth cluster $(d)$ generally comprised ashes generated after combusting mixes of wood (separately or together: ash, willow, acacia) and coals (coal III and coal II). In this cluster, the average leaching of chlorides and sulphates was the highest (in $\mathrm{mg} / \mathrm{dm}^{3}$ ): 1333 and 2204, respectively. Leaching of phosphates was also high-0.17.

With only two clusters (after merging cluster $a$ with cluster $b$; and cluster $c$ with cluster $d$ ), the average leaching of chlorides and sulphates in the first group was three times lower than in the second group $\left(a b \mathrm{Me}_{\mathrm{Cl}}=330 \mathrm{mg} / \mathrm{dm}^{3}, \mathrm{Me}_{\mathrm{SO}}=617 \mathrm{mg} / \mathrm{dm}^{3}, c d\right.$ $\mathrm{Me}_{\mathrm{Cl}}=1064 \mathrm{mg} / \mathrm{dm}^{3}, \mathrm{Me}_{\mathrm{SO}}=1793 \mathrm{mg} / \mathrm{dm}^{3}$ ), with a comparable result for phosphates $\left(a b \mathrm{Me}_{\mathrm{PO} 4}=0.23 \mathrm{mg} / \mathrm{dm}^{3}, c d \mathrm{Me}_{\mathrm{PO} 4}=0.21 \mathrm{mg} / \mathrm{dm}^{3}\right)$.

\subsection{Verification of Research Hypotheses}

Hypothesis 1 (H1). Does the addition of municipal waste (segregated and/or nonsegregated) to conventional and alternative energy fuels have a significant effect on the content of chlorides, sulphates, and phosphates in ashes generated from their combustion?

To verify the above hypothesis, the concentrations of the anions in individual groups of all the ashes studied were compared with the average concentrations of the three anions in ashes generated after combusting municipal waste (adopting these values as 100\%). As a result, it was concluded that the addition of municipal waste to the process of burning fuels in household furnaces did not significantly affect the increase in chloride, sulphate, and phosphate content in ashes (Figure 4). 


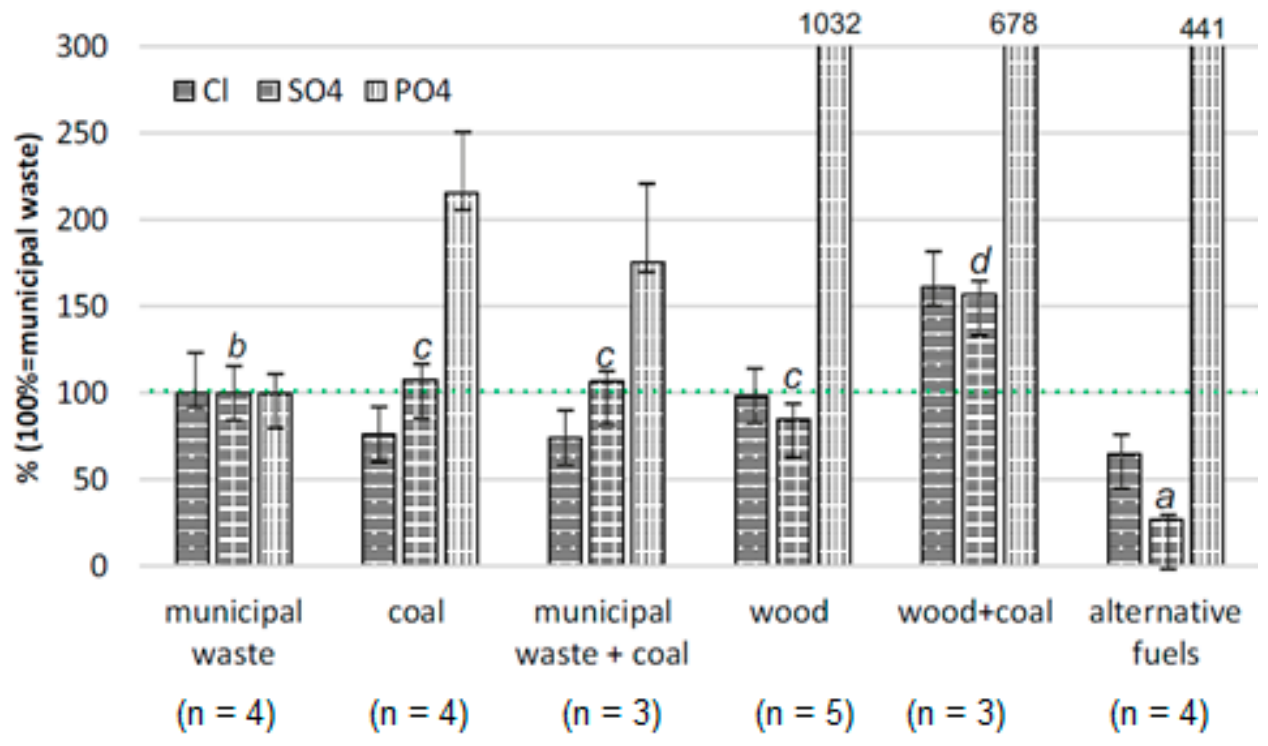

Figure 4. Comparison of the content of $\mathrm{Cl}^{-}, \mathrm{SO}_{4}{ }^{2-}$, and $\mathrm{PO}_{4}{ }^{3-}$ in ashes: wood, coal, and alternative fuels in relation to the content in ashes from municipal waste burned in home furnaces: $n$-number of samples; statistically significant differences marked, for $p=0.05$.

More detailed findings require further research and a greater number of samples of primary materials and the so-called mixes, as the material collected in this study is not sufficient to conduct accurate geochemical inference. Based on the independent samples $t$-test, the differences observed are statistically significant only in the case of sulphates (at $p=0.05)$.

Hypothesis 2 (H2). Does burning municipal waste in household furnaces significantly increase the environmental risk related to the content of chlorides, sulphates, and phosphates is ashes?

Comparing the results presented in Tables $2-4$ and Figure 4, it can be concluded that the addition of municipal waste to household furnaces is harmful to the environment, when high-quality fuels (such as high-grade coal and alternative fuels) are replaced with diapers and plywood. This is due to the possibility of an increased content of chlorides and phosphates (diapers), and chlorides and sulphates (plywood) in ashes generated after the combustion of these materials.

\section{Conclusions}

The analyses performed on 23 selected samples of ashes, which were the products of combusting conventional and alternative fuels mixed with segregated and non-segregated municipal waste in a household furnace, yielded the following conclusions:

1. A large amount of ash is generated after the combustion of willow wood, the mix of different types of wood, and straw. Burning of municipal waste, selected fractions, i.e., plastic-coated paper cartons and diapers, and the non-segregated fraction also produced a large amount of ash at the bottom of the furnace.

2. A large amount of non-combusted material was obtained for some wood species (e.g., ash), straw, sawdust, and several municipal waste fractions, namely plastic-coated paper cartons and diapers.

3. The addition of municipal waste to the process of burning fuels in household furnaces did not significantly affect the increase in chloride, sulphate, and phosphate content in ashes, the exception being diapers and plywood.

4. The amounts of anions leached in ash aqueous extracts decrease in the following order: 
- $\mathrm{Cl}^{-}$ash from: mix of wood and coals $>$wood (different species) $>$municipal waste $>$ alternative fuels $>$ mix of municipal waste and coals $>$ coals.

- $\mathrm{SO}_{4}{ }^{2-}$ ash from: mix of wood and coals $>$ wood (different species) $>$ coals $>$ mix of municipal waste and coals $>$ alternative fuels $>$ municipal waste.

- $\mathrm{PO}_{4}{ }^{3-}$ ash from: alternative fuels $>$ wood (different species) $>$ municipal waste $>$ coals $>$ mix of wood and coals $>$ mix of municipal waste and coals.

5. The analysis of ashes in terms of their reuse (as an additive to concrete) showed that the ashes from diapers did not meet the requirement set out in the standard, as they exceeded the allowable content of $\mathrm{PO}_{4}{ }^{3-}(>100 \mathrm{mg} / \mathrm{kg})$; nor did the ashes from the mixed municipal waste fraction and coal due to the high content of $\mathrm{Cl}^{-}(>0.1 \mathrm{wt} \%)$.

The results obtained for the entire set of samples and individual ash groups display high heterogeneity and variability. A particular problem related to reusing ashes is their heterogeneity and interactions between their components that take place in the total mass. The ashes definitely cannot be stored at inert waste landfills. Thus, the subject requires further research and a greater number of samples of primary materials to conduct further accurate geochemical inference.

Author Contributions: A.K. authored the project and designed the study; A.K. planned and supervised the experimental work, which was done by G.C.; A.K. contributed to the study design and discussed the data; A.K. performed the statistical analysis; A.K. revised the data; A.K. wrote the original draft of the paper. All authors contributed to the manuscript final form and approved the version to be submitted. All authors have read and agreed to the published version of the manuscript.

Funding: This research was financially support by AGH University of Science and Technology grant No.16.16.140.315.

Institutional Review Board Statement: Not applicable.

Informed Consent Statement: Not applicable.

Data Availability Statement: FORCAP modifications from the available website version are available upon request. Please e-mail Kicińska Alicja.

Conflicts of Interest: The authors declare no conflict of interest.

\section{References}

1. Kicińska, A. Chemical and mineral composition of fly ashes from home furnaces, and health and environmental risk related to their presence in the environment. Chemosphere 2019, 215, 574-585. [CrossRef]

2. Kicińska, A.; Mamak, M. Health risks associated with municipal waste combustion on the example of Laskowa commune (Southern Poland). Hum. Ecol. Risk Assess. Int. J. 2017, 23, 2087-2096. [CrossRef]

3. Barbosa, R.; Lapa, N.; Boavida, D.; Lopes, H.; Gulyurtlu, I.; Mendes, B. Co-combustion of coal and sewage sludge: Chemical and ecotoxicological properties of ashes. J. Hazard. Mater. 2009, 170, 902-909. [CrossRef] [PubMed]

4. Brancolia, P.; Boltona, K.; Eriksson, M. Environmental impacts of waste management and valorisation pathways for surplus bread in Sweden. Waste Manag. 2020, 117, 136-145. [CrossRef] [PubMed]

5. Galvín, A.P.; Ayuso, J.; García, I.; Jiménez, J.R.; Gutiérrez, F. The effect of compaction on the leaching and pollutant emission time of recycled aggregates from construction and demolition waste. J. Clean. Prod. 2014, 83, 294-304. [CrossRef]

6. Assi, A.; Bilo, F.; Zanoletti, A.; Ponti, J.; Valsesia, A.; La Spina, R.; Zacco, A.; Bontempi, E. Zero-waste approach in municipal solid waste incineration: Reuse of bottom ash to stabilize fly ash. J. Clean. Prod. 2020, 245, 118779. [CrossRef]

7. Hjelmar, O. Leachate from land disposal of coal fly ash. Waste Manag. Res. 1990, 8, 429-449. [CrossRef]

8. Saca, N.; Dimache, A.; Radu, L.R.; Iancu, I. Leaching behavior of some demolition wastes. J. Mater. Cycles Waste Manag. 2015, 19, 623-630. [CrossRef]

9. Twardowska, I.; Szczepanska, J. Solid waste: Terminological and long-term environmental risk assessment problems exempli-fied in a power plant fly ash study. Sci. Total Environ. 2002, 285, 29-51. [CrossRef]

10. Barbudo, A.; Galvin, A.P.; Agrela, F.; Ayuso, J.; Jiménez, J.R. Correlation analysis between sulphate content and leaching of sulphates in recycled aggregates from construction and demolition wastes. Waste Manag. 2012, 32, 1229-1235. [CrossRef]

11. Izquierdo, M.; Querol, X. Leaching behaviour of elements from coal combustion fly ash: An overview. Int. J. Coal Geol. 2012, 94, 54-66. [CrossRef]

12. Karuppiah, M.; Gupta, G. Toxicity of and metals in coal combustion ash leachate. J. Hazard. Mater. 1997, 56, 53-58. [CrossRef] 
13. Van Praagh, M.; Modin, H. Leaching of chloride, sulphate, heavy metals, dissolved organic carbon and phenolic organic pesticides from contaminated concrete. Waste Manag. 2016, 56, 352-358. [CrossRef] [PubMed]

14. Bassi, A.S.; Christensen, T.H.; Damgaard, A. Environmental performance of household waste management in Europe-An example of 7 countries. Waste Manag. 2017, 69, 545-557. [CrossRef]

15. Butera, S.; Christensen, T.H.; Astrup, T.F. Composition and leaching of construction and demolition waste: Inorganic elements and organic compounds. J. Hazard. Mater. 2014, 276, 302-311. [CrossRef] [PubMed]

16. Querol, X.; Juan, R.; Lopez-Soler, A.; Fernandez-Turiel, J.; Ruiz, C.R. Mobility of trace elements from coal and combustion wastes. Fuel 1996, 75, 821-838. [CrossRef]

17. Wilke, B.-M.; Riepert, F.; Koch, C.; Kühne, T. Ecotoxicological characterization of hazardous wastes. Ecotoxicol. Environ. Saf. 2008, 70, 283-293. [CrossRef] [PubMed]

18. Kanhar, A.H.; Chen, S.; Wang, F. Incineration Fly Ash and Its Treatment to Possible Utilization: A Review. Energies 2020, $13,6681$. [CrossRef]

19. Horak, J.; Kuboňová, L.; Bajer, S.; Dej, M.; Hopan, F.; Krpec, K.; Ochodek, T. Composition of ashes from the combustion of solid fuels and municipal waste in households. J. Environ. Manag. 2019, 248, 109269. [CrossRef]

20. Bachmaier, H.; Kuptz, D.; Hartmann, H. Wood Ashes from Grate-Fired Heat and Power Plants: Evaluation of Nutrient and Heavy Metal Contents. Sustainability 2021, 13, 5482. [CrossRef]

21. Link, S.; Yrjas, P.; Hupa, L. Ash melting behaviour of wheat straw blends with wood and reed. Renew. Energy 2018, 124, 11-20. [CrossRef]

22. Monedero, E.; Hernández, J.J.; Collado, R. Combustion-Related Properties of Poplar, Willow and Black Locust to be used as Fuels in Power Plants. Energies 2017, 10, 997. [CrossRef]

23. Suárez-Macías, J.; Terrones-Saeta, J.; Iglesias-Godino, F.; Corpas-Iglesias, F. Evaluation of Physical, Chemical, and Environmental Properties of Biomass Bottom Ash for Use as a Filler in Bituminous Mixtures. Sustainability 2021, 13, 4119. [CrossRef]

24. Statistic Poland. Available online: https://stat.gov.pl/obszary-tematyczne/srodowisko-energia (accessed on 20 April 2019).

25. Act of 14 December 2012 on Waste. J. Laws 2013, 21. Available online: https:/ / isap.sejm.gov.pl/isap.nsf/download.xsp/WDU201 30000021/T/D20130021L.pdf (accessed on 1 April 2021).

26. Announcement of the Marshal of the Parliament of the Republic of Poland of 7 November 2016 on the Publication of the Uniform Text of the Act on Waste. Available online: http:/ /isap.sejm.gov.pl/isap.nsf/DocDetails.xsp?id=WDU20160001987 (accessed on 1 April 2021).

27. European Council. Council Decision 2003/33/EC of 19 December 2002 establishing criteria and procedures for the acceptance of waste at landfills pursuant to Article 16 and Annex II to Directive 1999/31/EC. Off. J. Eur. Commun. 2002, L11, 27-49.

28. Minister of Environment, Regulation of the Minister of the Environment of 9 December 2014 on the Waste Catalogue. Off. J. 2014, 1923. Available online: http:/ /isap.sejm.gov.pl/isap.nsf/download.xsp/WDU20140001923/O/D20141923.pdf (accessed on 1 April 2021).

29. Standard PN-EN 12457-4:2006 Characterization of Waste-Leaching-Compliance Testing for Leaching of Granular Waste Materials and Sludge; Polish Committee for Standardization: Warsaw, Poland, 2006.

30. Querol, X.; Umana, J.C.; Alastuey, A.; Bertrana, C.; Lopez-Soler, A.; Plana, F. Extraction of water-soluble impurities from fly ash. Energy Sources 2000, 22, 733-750.

31. Kabata-Pendias, A.; Pendias, H. Biogeochemistry of Trace Elements; PWN: Warsaw, Poland, 1999.

32. Minister of Environment, Regulation of the Minister of the Environment of 21 December 2015 on the Criteria and Method of Assessing the State of Groundwater Bodies. Off. J. 2015, 2148. Available online: https:/ /isap.sejm.gov.pl/isap.nsf/DocDetails. xsp?id=WDU20160000085 (accessed on 1 April 2021).

33. Minister of Health, Regulation of the Minister of Health of 7 December 2017 on the Quality of Water Intended for Human Consumption. Off. J. 2017, 2294. Available online: http://isap.sejm.gov.pl/isap.nsf/DocDetails.xsp?id=WDU20170002294 (accessed on 1 April 2021).

34. The Act on Environmental Protection Law of 27 April 2001. J. Laws 2001, 627. Available online: https://isap.sejm.gov.pl/isap. nsf/download.xsp/WDU20010620627/U/D20010627Lj.pdf (accessed on 1 April 2021).

35. Kabata-Pendias, A.; Motowicka-Terelak, T.; Piotrowska, M.; Terelak, H.; Witek, T. Assessment of soil and plant contamination with heavy metals and sulfur. In Framework Guidelines for Agriculture; IUNG: Pulawy, Poland, 1993. (In Polish)

36. European Council. Council Directive 2008/98/EC of 19 November 2008 on Waste and Repealing Certain Directives. Off. J. Eur. Commun. 2008, L312/3, 99-126.

37. Standard PN-EN 450-1:2012 Fly Ash for Concrete-Part 1: Definitions, Specifications and Compliance Criteria; Polish Committee for Standardization: Warsaw, Poland, 2012.

38. Wasielewski, R.; Radko, T. The problem of managing waste from home furnaces. J. Ecol. Eng. 2018, 19, 36-44.

39. Pietrzak, S.; Majewska, Z.; Wesołowski, P. The suitability of degree of phosphorus saturation indicator to assess the risk of losses this compound by runoff to surface water-Case study. Water Environ. Rural Areas 2016, 16, 89-98.

40. Kanclerz, J.; Wiatrowska, K.; Adamska, A. Phosphorous concentration in surface water of Gorzuchowskie Lake catchment. Pol. J. Agron. 2015, 22, 10-17.

41. Igras, J. Assessment of phosphorus losses from agricultural production in Poland. Fertil. Fertil. 2002, 4, $275-285$. 